\title{
Research and Practice of English Major Writing Class for the Coordinated Development of Language, Critical Thinking and Discipline Competence under CLIL Framework
}

Tian Dong ${ }^{1}$, Jingjing Zhang ${ }^{2 *}$

${ }^{1}$ Professor in School of Foreign Languages, North China Electric Power University, NO 689 Road, North District, Baoding, Hebei, China

${ }^{2}$ Graduate Student in School of Foreign Languages, North China Electric Power University, NO 689 Road, North District, Baoding, Hebei, China

DOI: $10.36348 /$ sijll.2020.v03i12.002

| Received: 26.11.2020 | Accepted: 09.12.2020 | Published: 13.12.2020

*Corresponding author: Jingjing Zhang

\section{Abstract}

The rapid development of China's economy and society needs innovative and inter-disciplinary English talents. However, traditional skill-oriented foreign language teaching leads to the absence of English major students' critical thinking. Content and Language Integrated Learningcan solve this problem well. This article integrates Content and Language Integrated Learning with principles of language and critical thinking integrated teaching to explore how to make effective instructional designs in English major writhing class to develop students' critical thinking, with the expectation of providing instructional ideas for college English teachers.

Keywords: Critical thinking ability, Discipline competence, Content and language integrated learning, English major writing class.

Copyright (C) 2020 The Author(s): This is an open-access article distributed under the terms of the Creative Commons Attribution 4.0 International License (CC BY-NC 4.0) which permits unrestricted use, distribution, and reproduction in any medium for non-commercial use provided the original author and source are credited.

\section{INTRODUCTION}

China's economy and society has experienced rapid development and cooperation with international countries has been deepened since the implementation of reform and opening-up policy, which makes higher requirements for the development of English talents. English teaching syllabus for English majors in colleges and universities published in 2000 clearly claims that the aim of English major is to develop inter-disciplinary English talents withsolid foundation of English basic knowledge, broad cultural knowledge and ability of using English expertlyto perform different work. Meanwhile, some opinions on the reform of undergraduate education for foreign language majors published by Foreign Language Teaching Steering Committee of Colleges and Universities in 1998 makes it clear that English talents in 21 st century should own the following five kinds of traits: solid basic skills, a wide range of knowledge, certain professional knowledge, strong ability and good quality. But for a long time, the cultivation of English major students only focuses on the development of fundamental skills including listening, speaking, and reading and writing, which overlooks the development of critical thinking ability and results in the absence of most English major students' critical thinking ability. Compared to other liberal arts majors, English major students lack high ability of analysis, synthesis, judgement, reasoning, thinking and discrimination in logical thinking, which is the obvious manifestation of absence of critical thinking ability [1]. In order to cultivateinter-disciplinary and innovative talents, the cultivation of English major talents in China should pay attention to develop students' critical thinking ability. The concept of language and critical thinking integrated teaching advocates that through the critical thinking activities of listening, speaking, reading and writing, the English learning and critical thinking development can be integrated with each other so as to improve the English ability and critical thinking ability at the same time [2]. Since the concept of language and critical thinking integrated teaching was popular in college English major teachers, a great many of experts in English language have studied the specific methods of its implementation. You-Zhong Sun [2] proposed eight basic principles of language and critical thinking integrated teaching. One of them is using language materials with challenge of cognition, which is in accordance with Content and Language Integrated Learning (CLIL). The teaching idea of Content and Language Integrated Learning advocates teaching innovative, meaningful and systematic knowledge or information which can stimulate students' motivation for learning and can be included in system of subject knowledgestudents need to grasp. Teachers teach 
subject knowledge with target language and students discuss and analyze the subject knowledge with target language. At last, students improve their language ability on the base of mastering subject knowledge. This teaching method can deal withthe problem of English students' absence of critical thinking to a large extent. This article integrates the pyramid lesson planning proposed by Mayer [3] under the Content and Language Integrated Learning with eight basic principles of language and critical thinking integrated teaching proposed by You-Zhong Sun [2] to explore the specific implementation strategies to develop college English students' critical thinking ability in writing class.

\section{Content and language integrated learning}

Content and Language Integrated Learningwas proposed and adopted by European education administrators, researchers and teaching practitioners in 1990s [4]. It derived from Canadian Content- based Instruction model and got a large amount of attention in Europe. European experts have conducted many studies on it and made fruitful results. Then it has been introduced to other countries. Content and Language Integrated Learning was proposed on the base of Hyme's communicative competence theory and Halliday's functional linguistics theory. In terms of the definition of CLIL, Barwell [5] thought that CLIL is the teaching or learning of language and subject contents. This definition doesn't specify the variety of language and even not exclude the possibility of using native language. Georgiou [6] claimed that CLIL is a teaching strategy which means that teachers use foreign language to teach non-linguistic subject contents in order to make learners acquire subject knowledge and language ability. This definition defines the language to foreign language. Coyle et al. [7] thought that CLIL is a teaching method to teach language and contents at the same time with an additional language such as second language, foreign language and so on. Coyle [7] conceived a 4C systematic framework for the curriculum of CLIL. This framework includes four elements: content, cognition, communication and culture. These four elements are not only independent but also complementary to each other so that they form an organic unity of subject contents learning and language learning. The content not only refers to the acquired knowledge and ability, but also learners'internal knowledge and ability that have conceived and improved. Content and cognition (learning and thinking) relates to each other. Learners deepen the understanding of knowledgeand reconstruct the content and cognition processthrough analyzing the language of subject contents. Communication refers to the interactivity of significant learning environment in learning process. Culture refers to the cross-culture awareness between native language and target language. Content is the start, and the aim of communication is achieved based on the cross-cultural awareness in the cognition of analyzing the required language of content knowledge [8]. The study on CLIL in foreign countries mainly focuses on two aspects which are classroom teaching and teacher development. In order to solve the problems resulted from the skilloriented foreign language teaching, CLIL was applied to language teaching in China in 1990s, and later many researchers have conducted a large amount of studies on it. Yue-Qin Guo and Xiu-Juan Wu [9] adopted CLIL to college English writing class considering its advantages. The study showed that CLIL has a great effect on improving students' English writing ability. Compared to traditional teaching method, CLIL integrates subject knowledge and language, which makes the language be used in a specific and real situation. The choice of language and the organization of text are more operative. Meanwhile, it broadens students' horizon, improves their cross-culture awareness and ability, cognation level, and the ability of using language. Fu-Quan Huang and Ling-Li Li [10] studied and analyzed the effective implementation strategies of CLIL including pyramid lesson planning,

key visual classroom model, pedagogy of multiliteracies framework and dual-matrix assessment. These strategies provide new teaching reform ways for foreign language education even the whole education realm.

\section{Critical thinking ability}

Critical thinking ability is one part of thinking skills. During the senior stage of language learning, critical thinkingability needs to be included in the notion of language ability. BrianRoper, president of North London Collegiate School, also claims that higher education should develop students' ability of abstract thinking, logical thinking ability, effective reasoning ability and ability to evaluate arguments [11]. These several kinds of abilities can be included in the critical thinking ability. You-Zhong Sun [2] points out that critical thinking ability is the ability to interpret, analyze and evaluate the input information (oral or written), and the ability to reason and explain based on the indirect or direct acquisition of information.

The study on critical thinking ability has received a large amount of attention in west countries especially America. These studies mainly focus on the definition, measuring tool and teaching. In terms of definition, they have constructed dual-dimension structural model and ternary structure model of critical thinking ability. In terms of measuring tool, the number of developed tool has reached over 20. The most authoritative study on measuring tool of critical thinking ability in China is conducted by the research team led by Qiu-Fang Wen. They have constructed a conceptual framework for assessing foreign language major students' critical thinking skills. This framework consists of two levels: the first level is the meta-critical thinking skill, and the second level is critical thinking skill. The meta-critical thinking skill monitors and governs the critical thinking skill. The critical thinking skill includes two components: cognition and affection. 
The cognitioncomponent comprises the cognitive skills and standards which the cognitive skills are supposed to meet, and the affection component possesses typical affective attributes. The cognitive skills include analysis, inference and evaluation, and the standards are clarity, relevance, logic, depth and flexibility.

In recent years, with the increasing attention to English major students' lack of critical thinking ability, principles of language and critical thinking integrated teaching are popular in college teachers.Language and critical thinking integrated teaching supports this kind of view of language and language learning: language is supposed to be an approachto develop higher thinking skills. In language teaching, it doesn't mean that studentslearn language for the sake of learning language, but for developing their thinking skills, and applying thinking skills out of class [12]. You-Zhong Sun [2] proposed eight basic principles of language and critical thinking integrated teaching: targeting, evaluating, routinizing, reflecting, inquiring, fulfilling, integrating and content. The initial of these eight English words can form an English word---TERRIFIC.

\section{INSTRUCTIONAL DESIGN}

This article integrates the pyramid lesson planning proposed by Mayer [3] with eight basic principles of language and critical thinking integrated teaching proposed by You-Zhong Sun [3] to explore how to make instructional designs in English major writing class to develop students' critical thinking ability.

Meyer [3] proposed pyramid lesson planning on the base of $4 \mathrm{c}$ curriculum framework. Pyramid lesson planning comprises four stages which are topic choice, media development, task design and assignment. The relationship among these four stages is progressive.

\section{(1) Topic Choice}

Topic choice of subject content is the first step of lesson planning. Certain topic is the base of lesson planning and resource construction in Content and Language Integrated Learning. So in terms of different subject content, choosing suitable topic is very important. Topic must relate to students' major learning and real life. In terms of English major writing class, the topic can relate to English-speaking countries' culture such as culture difference, culture conflict and culture assimilation.

\section{(2) Media Development}

The second stage is media development which includes developing learning strategies and input scaffold. In order to help students learn constructively by themselves, teachers need to instruct students to learn effectively, that's to say, to master learning skills and strategies. Input scaffold aims to reduce the cognition and language load in input contents so as to help students understand and grasp subject knowledge and language knowledge in instruction resources. Considering students' different learning styles and different level of intelligence, teachers ought to utilize multiple input models and highly personalized resources [10]. Before class, teachers can utilize information teaching platforms such as 'renrentong' or the free platforms provided by the third party to publish tasks, and ask students to collect the resources relating to writing resources and upload to the platform. Other students can express their ideas and give a mark after watching the uploading resources. Meanwhile, teachers can finish the process evaluation through the data of real-time information collection. In class, teachers can ask students to simply share the collecting topic resources with target language. After that, teachers can make a supplementary explanation in terms of the expertise and technical term in resources. Take 'cultural assimilation' as an example, teachers need to interpret the connotation of it with the help of interactive whiteboard technology and digital resources such as animation, video, and mini-lecture [13] or computer cognitive tools such as concept map, semantic graph to present visually and intuitively during the interpretation process (9]. Besides, teachers ought to explain the content with target language, and utilize native language appropriately, which can help students remove language barriers that affect the understanding of the word 'assimilation'.

\section{(3) Task Design}

The third part is task design. Task design must meet two aspects of requirements. The first requirement is triggering off advanced thinking skills. Effective teaching means that the learning situationcreated is challenging to students and can promote the development of students' various kinds of thinking skills. The second requirement is achieving different kinds of interactive communicationsthrough group activity and mate interaction. Students make frequent and meaningful communications in different kinds of interactive activities amid finishing tasks, which helps them understand and expand the content of the subject knowledge. In order to make sure students accomplish a series of tasks, teachers should play the role of output scaffolds including providing required language in learning subject contents such as phrases and so on. In fact, students' interactions and outputs are the product of tasks, so task design is the key point in lesson planning [10]. In English major writing class, task design can follow ThinkPair-Share activities proposed by Harvard University's expert Ritchhart et al. The procedure of this activity is that 1) the teacher proposes a speculative and challenging question in terms of the writing topic 2) students think of answers to the 
question by themselves 3) students have a discussion with several partners in a group 4) each group chooses one presenter to share their opinionin class. This activity conforms to the principle of routinizing in language and critical thinking integrated teaching. The teacher should set up rules for the group discussion. For example, students express their opinions in order and should respect others'opinions; if students don't agree with others' conceptions, they can ask others to explain; at last, students should try to reach consensus [14]. After sharing opinions, the teacher should arrange reflection activity which is toask each group to reflect the process of analyzing and solving problems just now.Each group member shares his meta-thinking, illustrates his motivation, states his strategy of solving the problem and the suitability of the strategy, and describes his thinking map to monitor his thinking process well in the future. What's more, each group member should write journal of reflection regularly to record the development process of his thinking skills, which is helpful for them to reflect his thinking features and the weakness so as to further work out the method to improve thinking skills. This reflection activity adheres to theprinciple of reflecting in language and critical thinking integrated teaching.

\section{(4) Assignment}

The last stage is assignment. This stage is mainly to design practice activities in terms of the aim of subject contents and language learning. Teachers can ask students to have writing in accordance with the topicdiscussed. After finishing writing, students can upload the writing assignment to the platform, and other students can evaluateit. What deserves attention is that teachers must provide students with writing evaluation criteria that include critical thinking dimensionand then students can utilize these criteria to have peer review. This activity accords with the principle of evaluating inlanguage and critical thinking integrated teaching.

\section{CONCLUSION}

In the era of development of globalization, society needs inter-disciplinary and innovative English talents. However, students without critical thinking ability can't meet the requirements for such talents. So developing English major students' critical thinking ability is the urgent matter. Content and Language Integrated Learning can improve students' critical thinking ability. It integrates subject contents learning with language learning to improve cognition development. So college English teachers can apply the useful implementation strategies of Content and
Language Integrated Learning to the English major writing class and other kinds of class. They can formulate instruction activities according to principles of language and critical thinking integrated teaching so as to improve English major students' critical thinking ability.

\section{ACKNOWLEDGEMENT}

This research was financially supported by HeBei Education Department Project (2019GJJG631).

\section{REFERENCES}

1. Huang, Y. S. (1998). The Lack of Critical Thinking. Foreign Language and Their Teaching.

2. Sun, Y. Z. (2019). Principles of Language and Critical Thinking Integrated Teaching. Foreign Language Teaching and Research.

3. Meyer O. (2010). Towards quality-CLIL: Success20151 planning and teaching strategies. Pulso, (33), 11-29.

4. Marsh, D. (2002). CLIL/EMILE: The European Dimension. University of Jyväskylä.

5. Barwell, R. (2005). Integrating language and content: Issues from the mathematics classroom. Linguistics and education, 16(2), 205218.

6. Georgiou, S. (2012). Reviewing the puzzle of CLIL . ELT Journal, 66(4), 495 - 504.

7. Coyle, D., Hood, P., \& D. Marsh. (2010). Content and Language Integrated Learning. Cambridge University Press.

8. Guo, Y. Q., \& Wu, X. J. (2013). On the Application of CLIL in College English Writing. Foreign Language and Literature.

9. Du, J., Li, Z. J., \& Guo, L. W. (2013). The Study on Strategy of Information Teaching to Promote Deep Learning. e-Education Research.

10. Huang, F. Q., \& Li, L. L. (2015). The Implementation Approach of Content and Language Integrated Learning. Foreign Language World.

11. Chapman, J. (2005). The development of the assessment of thinking skills, from http://www.cambridgeassessment.org.uk/ca/digitalAssets/109493.

12. Richards, J., \& T. Rodgers. (2014). Approaches and Methods in Language Teaching. Cambridge, CUP.

13. Wang, C. H. (2006). To Achieve Information Teaching through Interactive Whiteboard Technology. Journal of Shandong Normal University.

14. Mercer, N., \& K. Littleton. (2007). Dialogue and the Development of Children's Thinking. New York: Routledge. 